\title{
Impacts of the Tax Package in 2021 on the Taxation of Employees and Self-Employed People in the Czech Republic
}

\author{
Jiří SLEZÁK* and Barbora KAHÁNKOVÁ \\ Technical University of Ostrava, Ostrava, Czech Republic; jiri.slezak@vsb.cz; barbora.kahankova@vsb.cz \\ * Corresponding author: jiri.slezak@vsb.cz
}

\begin{abstract}
The presented article focuses on the effects of the tax package on the taxation of employees' income and on self-employed people in the Czech Republic. As part of the adopted tax changes, the super-gross wage is abolished, a catering flat rate for employees is introduced, and, among other things, a flat tax is introduced for the self-employed. The aim of the contribution is to analyze these tax changes. Model examples show what the abolition of super-gross wage means for employees and whether this fact is beneficial for them, as stated by tax policy makers. Furthermore, the essence of the catering flat rate is introduced in order to determine when it is advantageous for employees and when for employers. Finally, the introduction of a flat tax is analyzed with regard to its advantage for the selfemployed. Model situations have shown that the abolition of the super-gross wage represents in all cases an increase in the net wage for employees. In the case of catering and the introduction of a flat tax, the result depends on the amount of the catering flat rate or more precisely the amount of income and expenditure of the self-employed person.
\end{abstract}

Keywords: catering flat rate; flat tax; super-gross wage

JEL Classification: $\mathrm{H} 24 ; \mathrm{K} 34$

\section{Introduction}

The current time is characterized not only by permanent changes in society, but also by changes in the economy and politics. In 2020, a tax package was adopted in the Czech Republic, which contains a number of changes in the tax area which come into effect from 2021. One of the most significant changes is the abolition of the super-gross wage, which was introduced in 2008. The abolition of the super-gross wage was discussed since its inception, but the abolition occurs only now. The abolition of the super-gross wage could, in addition to simplifying the calculation of the employee's wage, also result in an increase in the amount to be paid (KPMG, 2020a). On current trends in labor taxation, for example in (Sokolovska, 2018). On the system of taxation of natural persons and the development of the national economy, for example in (Tikhonova et al., 2018).

Considering the fact that the tax liability is calculated from the super-gross wage, the effective taxation in 2020 is up to $20.1 \%$. In addition, since 2013, taxpayers who have an income higher than 4 times the average monthly wage also pay a so-called solidarity surcharge of $7 \%$ (Ministerstvo financí, 2020a). The above fact is also the reason why the Czech 
Republic ranks among the countries with the highest tax measurement of labor (Slezák et al., 2020). Reducing the tax burden could also affect the economic growth of the Czech Republic, more for example in (Alfonso \& Alegre, 2008) or (King \& Rebelo, 1990). The influence of wages and corporate income taxes, for example in (Fuest et al., 2018).

From 2021, the super-gross wage will be abolished and the tax liability will be determined directly from the gross wage, through a $15 \%$ tax rate. If an employee receives a gross salary in the minimum amount of CZK 141,764, he is taxed at a rate of $23 \%$. Furthermore, the discount per taxpayer is increased to CZK 2,320, and to CZK 2,570 in 2020 (KPMG, 2020b).

In 2020, employers in the Czech Republic were able to provide their employees with two types of benefits related to catering, namely company meals directly at the workplace and the provision of meal vouchers (Portal.pohoda, 2020a).

Since 2021, the so-called catering flat rate has been added to the above-mentioned benefits, which represents a contribution to catering in the form of money. Given that some employers do not offer their employees meals at the workplace nor provide them with meal vouchers due to administration, a flat rate appears to be a beneficial advantage that could be achieved by many more employees. The tax package supplements $\S 6$ par. 9 letter $b$ ) of the Act on Income Taxes with this cash contribution, which according to the Labour Code is exempted up to $70 \%$ of the upper limit of the meal allowance that can be provided to employees remunerated for a salary on a business trip lasting 5 to 12 hours. Such a contribution will also be tax deductible on the part of the employer. The upper limit of the meal allowance for a business trip lasting 5 to 12 hours was CZK 108 for 2020. The calculation of the total exempt amount for employees is 70\% of CZK $108=$ CZK 75.60 (Ministerstvo financí, 2020b).

Since 2021, the possibility of paying a flat tax of CZK 5,469 has been introduced for selfemployed people, whose income amounts to a maximum of CZK 1,000,000 per year. The flatrate tax includes a minimum health insurance contribution of CZK 2,393, income tax of CZK 100 and an increased minimum social insurance contribution of $15 \%$, which corresponds to CZK 2,976, but these amounts change every year. (Finanční správa, 2020).

The benefits of the flat tax include reducing administrative burdens. It is not necessary to file a tax return or summary of income and expenses for the health insurance company and the social security administration. In addition to time savings, it also applies to financial savings, for example, to reduce expenses for tax advisors. Furthermore, thanks to the increase of $15 \%$ of the minimum social insurance, there is an increase in pensions for taxpayers, which pay only the minimum amount and at the same time there is an increase of the pension insurance and thus the pension system. On the contrary, the disadvantages include the impossibility of applying tax rebates and tax benefits for children, which is a significant problem for taxpayers applying the tax bonus (Portal.pohoda, 2020b).

Other innovations adopted in the tax area include the abolition of real estate acquisition tax and the related reduction of the deduction of interest on housing loans as a non-taxable part of the tax base, raising the limit for depreciation of fixed assets to CZK 80,000, or abolishing tax depreciation of intangible assets (KPMG, 2020b). 
The aim of the contribution is to focus on the above-mentioned issues in 2021 in comparison with its previous adjustment in 2020 and to assess the benefits of the tax changes for employees, employers and the self-employed. Finally, all the conclusions are summarized.

\section{Methodology}

The methods used in this article correspond to its focus. It is mainly a method of description, analysis and comparison. Furthermore, the method of procedure was used, which is based on going from basic parts up to more complex categories. All the main and major findings, results and discussion are summarized mainly using the method of synthesis. More about these methods, for example in (Hendl, 2005).

In 2020, the calculation of the net wage consists of the gross wage, which is increased by social and health insurance, which is paid for the employee by the employer (the so-called super-gross wage). The amount of social insurance in 2020 is $24.8 \%$ and the health insurance rate is $9 \%$ (Krajňák, 2020a). Super-gross wages (SGW) for employees represent tax base according to $\S 6$ - Income from dependent activity. After rounding the tax base up to CZK 100 (in the case of a monthly calculation), the tax liability is then calculated using the $15 \%$ tax rate. It is possible to deduct tax rebates (for example, a taxpayer discount of CZK 2,070) and a tax benefit for children from the tax liability calculated in this way. Furthermore, employees are obliged to pay social and health insurance (SHI) in the amount of $6.5 \%$ and $4.5 \%$ of gross wages (GW). Finally, the tax liability after tax rebates, tax benefits and social and health insurance contributions paid by the employee are deducted from the gross salary (Krajňák, 2020b).

The net salary in 2020 is calculated as follows:

$$
\text { Net salary }=G W-(S G W * 0.15-\text { tax rebates })-S H I
$$

The net salary in 2021 is calculated as follows:

$$
\text { Net salary }=G W-\left(G W^{*} 0.15-\text { tax rebates }\right)-S H I
$$

The minimum salary for 2021 in the amount of CZK 15,000 (in 2020 in the amount of CZK $14,600)$ and the average salary for social insurance purposes for 2021 in the amount of CZK 35,441 (in 2020 in the amount of CZK 34,835) was obtained from the Ministry of Labor and Social Affairs (MPSV, 2020a) and (MPSV, 2020b).

\section{Results}

In case of the abolition of the super-gross wage, two hypothetical situations are modeled (year $2020 \times 2021$ ), the aim is to determine whether the abolition of the super-gross wage is advantageous for employees or not. The first hypothetical situation shows the calculation of the net wage in 2020 for different income levels. The gross wage of CZK 15,200 represents the level of the minimum wage in the Czech Republic in 2021, the gross wage of CZK 35,441 represents the average wage in the Czech Republic in the same year. The second hypothetical situation is shown by the calculation of the net wage in 2021, for the same income levels as in 
the previous case (for better comparability, no increase in these categories of wage income for 2020 is expected).

In case of the catering flat rate, three hypothetical situations are modeled, the aim is to determine how the given fact affects employees and the employer and which option is the most advantageous for the mentioned groups. The first hypothetical situation - Catering flat rate worth CZK 54. The second hypothetical situation - Catering flat rate worth 75.60 CZK. The third hypothetical situation - Catering flat rate worth CZK 90.

In case of the introduction of a flat tax, three hypothetical situations are modeled in order to determine whether a flat tax is advantageous or not for individual types of income of selfemployed people (CZK 200,000, CZK 500,000 and CZK 800,000). Expenditure is in all situations set at a percentage of revenue of $40 \%$ and $60 \%$. The tax base is determined as the difference between income and expenses and the tax rate is $15 \%$ of the tax base. Furthermore, we consider that the taxpayer applies only a taxpayer discount, so no other discounts or tax benefits are taken into consideration. The annual discount per taxpayer in 2021 is CZK 27,840. The pension insurance rate is $29.2 \%$ and is calculated from the tax base reduced by $50 \%$. The minimum deposit for pension insurance is CZK 2,588 per month. The health insurance rate is $13.5 \%$ and is calculated from the tax base reduced by $50 \%$. However, the minimum deposit for health insurance is CZK 2,393 per month (Finanční správa, 2020).

\subsection{Abolition of the Super-gross Wage}

Table 1 below contains the calculation of the net wage in 2020 and for comparison also in 2021, for a taxpayer who is only entitled to a taxpayer discount whose monthly amount in 2020 is CZK 2,070 and in 2021 is 2,320 CZK. Additional discounts are not considered.

Table 1. Calculation of net wage in 2020 and in 2021 in CZK

\begin{tabular}{|c|c|c|c|c|}
\hline Text & $\mathbf{2 0 2 0}$ & $\mathbf{2 0 2 1}$ & $\mathbf{2 0 2 0}$ & $\mathbf{2 0 2 1}$ \\
\hline Gross wage & 15,200 & 15,200 & 35,441 & 35,441 \\
\hline Social insurance $(24.8 \%)$ & 3,770 & & 8,790 & \\
\hline Health insurance (9\%) & 1,368 & & 3,190 & \\
\hline Super-gross wage & 20,338 & 15,200 & 47,421 & 35,441 \\
\hline Tax before discounts & 3,060 & 2,280 & 7,125 & 5,325 \\
\hline Tax after discounts & 990 & 0 & 5,055 & 3,005 \\
\hline Social insurance $(6.5 \%)$ & 988 & 988 & 2,304 & 2,304 \\
\hline Health insurance (4.5\%) & 684 & 684 & 1,595 & 1,595 \\
\hline Net wage & 12,538 & 13,528 & 26,487 & 28,537 \\
\hline
\end{tabular}

As can be seen from Table 1, in case of the abolition of the super-gross wage, the taxpayer's share of the net wage is increased in all analyzed cases. In case of a gross wage of 15,200 , it is by CZK 990, which represents an increase of $7.3 \%$. In case of gross wages of CZK 35,441 , this is CZK 2,050, which represents an increase of $7.9 \%$. No other tax rebates or tax benefits were taken into consideration. In case of a taxpayer who is entitled to further rebates (for example student, etc.) the tax savings would be greater, in some cases the taxpayer would not have to pay at all, and, conversely, the tax could be refunded. 
Figure 1 shows the effects of changes in the calculation of salary for 2020 and 2021 for various types of gross salaries.

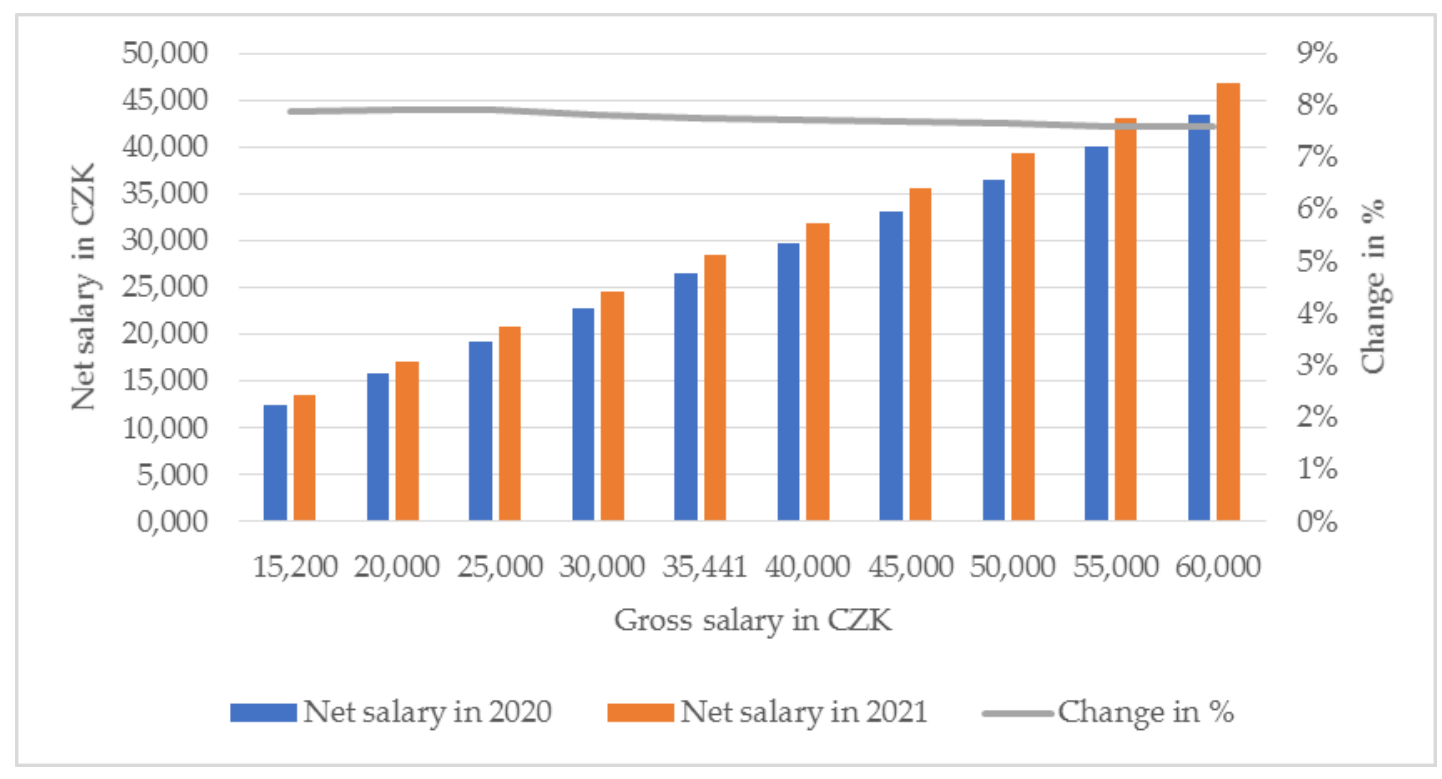

Figure 1. Impact of the change in the calculation of net salaries in 2020 and 2021 for various gross salaries

Figure 1 shows that the net salary is growing for all monitored incomes. It can be seen that with increasing gross salaries, net salaries increase. The increase in net salaries in 2021 is around $8 \%$, depending on the amount of gross salaries.

To clarify the issue, Table 2 shows the calculation of tax in the annual settlement in comparison with the years 2020 and 2021, for the monthly minimum and monthly average salary for 2021. For the purposes of annual tax settlement, the taxpayer applies life insurance in the amount of CZK 12,000 as non-taxable part of the tax base, and paid CZK 10,000 in interest on the building society account.

Table 2. Impact of the abolition of the super-gross salary in the annual tax settlement in 2020 and 2021

\begin{tabular}{|c|c|c|c|c|}
\hline Text & $\mathbf{2 0 2 0}$ & $\mathbf{2 0 2 1}$ & $\mathbf{2 0 2 0}$ & $\mathbf{2 0 2 1}$ \\
\hline Partial tax base §6 & 182,400 & 182,400 & 425,292 & 425,292 \\
\hline Tax base & 244,052 & 182,400 & 569,042 & 425,292 \\
\hline $\begin{array}{c}\text { Tax base after deducting } \\
\text { non-taxable parts }\end{array}$ & 222,052 & 160,400 & 547,042 & 403,292 \\
\hline Tax & 33,315 & 24,060 & 82,065 & 60,495 \\
\hline Tax after discount & 8,475 & 0 & 57,225 & 32,655 \\
\hline Deposits deducted & 11,880 & 0 & 60,660 & 36,060 \\
\hline Amount overpaid & 3,405 & 0 & 3,435 & 3,405 \\
\hline
\end{tabular}

Table 3 shows the taxation situation if the taxpayer works as an employee and if the taxpayer works as a self-employed person, also an application and the minimum amount for social and health insurance and expenses of income (60\% expenditure lump sum). The monthly minimum salary and the monthly average salary in 2021 were used as the starting amount. 
Table 3. Taxation of employees and self-employed in 2021

\begin{tabular}{|c|c|c|c|c|}
\hline Text & Employee & Self-Employed & Employee & Self-Employed \\
\hline Annual income & 182,400 & 182,400 & 425,292 & 425,292 \\
\hline Tax base & 182,400 & 72,960 & 425,292 & 170,117 \\
\hline Tax & 22,860 & 10,950 & 63,795 & 25,530 \\
\hline Tax after discount & 0 & 0 & 35,955 & 0 \\
\hline $\begin{array}{c}\text { Social and health } \\
\text { insurance (employee) }\end{array}$ & 20,064 & 59,772 & 46,783 & 0 \\
\hline $\begin{array}{c}\text { Social and health } \\
\text { insurance (employer) }\end{array}$ & 61,652 & 0 & 143,750 & 3672 \\
\hline Net income & 162,336 & 122,628 & 342,554 & 320 \\
\hline
\end{tabular}

Table 3 shows that from the point of view of taxation, it is difficult to determine what is more advantageous to the taxpayer, as it depends on the amount of annual income, expenses and the amount of insurance premiums that the self-employed person wants to claim. However, it can be said that with lower annual amounts, it is more advantageous to the taxpayer to work as an employee, as his taxation will be lower and thus higher net income. With higher annual amounts and in the case where the self-employed person intends to claim insurance premiums in minimum amounts, it is more advantageous to the taxpayer to do business. However, if the self-employed pays only a minimal amount of insurance premiums, this will have an impact on his pensions and unemployment benefits, which will be significantly lower than for employees. Conversely, if he claims higher premiums, his overall taxation may be higher than for employees. Compared to employees, self-employed persons are not entitled to nursing allowances and their administrative burden related to taxes is also increasing. Furthermore, self-employed persons do not have a legal right to leave, legal protection according to the Labor Code or Entitlement to sickness benefits in case of incapacity for work (if they do not pay it voluntarily). As already mentioned, it is not possible to clearly determine what is more advantageous to the taxpayer, for the reasons mentioned above. Compared to 2020, however, the differences in taxation have been reduced, as the abolition of the super-gross salary had no effect on taxation for the self-employed (Finance, 2016).

\subsection{Introduction of a Catering Flat Rate}

In case of applying a catering flat rate in the amount of CZK 54, the amount of CZK 54 is exempt income for employees, which will not be subject to social and health insurance in 2021, and the amount of CZK 54 is a tax-deductible expense for employers.

In case of applying a catering flat rate in the amount of CZK 75,6, the employee's amount of CZK 75.6 is exempt income, which in 2021 will not be subject to social and health insurance and for the employer the amount of CZK 75.6 represents a tax-deductible expense.

In case of applying a catering flat rate of CZK 90, the amount of CZK 75.6 is exempt income for employees, which in 2021 will not be subject to social and health insurance and the remaining CZK 14.4 represent income according to $\S 6$ - Income from dependent activities and is subject to taxation and therefore will be necessary to pay for social and health insurance. For employers, the amount of CZK 90 represents a tax-deductible expense. 
In the three model situations mentioned above, we have shown the meaning of the catering flat rate. For employers, it is always a tax-deductible expense, whatever its amount. On the other hand, the situation is a bit more difficult for an employee. If the employee is provided with a catering flat rate of CZK 75.6 or less, the entire amount is exempt from tax and social and health insurance. If a higher amount is provided to the employee, the value of the catering flat rate up to CZK 75.6 is again exempt, but any amount above the stated value is subject to taxation and social and health insurance. In the case of a catering flat rate of CZK 54 and assuming 21 working days a month, the employee will receive CZK 1,134 in addition to his net salary. In the case of a catering flat rate of CZK 75.6 and assuming 21 working days a month, the employee will receive CZK 1,587.6 in addition to his net salary. In the case of a catering flat rate of CZK 90 and assuming 21 working days a month, the employee will receive CZK 1,587.6 in addition to his net salary and the remaining CZK 302.4 will be part of his gross salary. It is expected that thanks to the introduction of a catering flat rate, more employees will be rewarded in this way, even those who have not yet received any similar benefit from employers. However, it is entirely up to the employer how and in what amount he will provide this benefit.

\subsection{Introduction of a Flat Rate}

Table 4 below shows the results of the hypothetical situations set out in Chapter 3 percentage of revenue of $60 \%$ ).

Table 4. Introduction of a flat rate

\begin{tabular}{|c|c|c|c|c|c|}
\hline Text & $\mathbf{2 0 2 1}$ & $\mathbf{2 0 2 1}$ & $\mathbf{2 0 2 1}$ & $\mathbf{2 0 2 1}$ & $\mathbf{2 0 2 1}$ \\
\hline Income & 200,000 & 400,000 & 600,000 & 800,000 & $1,000,000$ \\
\hline Expenditure (60\%) & 120,000 & 240,000 & 360,000 & 480,000 & 600,000 \\
\hline Tax base & 80,000 & 160,000 & 240,000 & 320,000 & 400,000 \\
\hline Tax & 12,000 & 24000 & 36,000 & 48,000 & 60,000 \\
\hline Tax after discount & 0 & 0 & 8,160 & 20,160 & 32,160 \\
\hline Pension insurance & 31,056 & 31,056 & 31,056 & 31,056 & 31,056 \\
\hline Health insurance & 28,716 & 28,716 & 28,716 & 28,716 & 28,716 \\
\hline
\end{tabular}

For taxpayers with income of CZK 200,000, the total annual levies amount to CZK 59,772, after conversion to months, the amount is CZK 4,981, which is CZK 488 less per month (CZK 5,856 per year) in comparison to flat rate and in this case a flat rate is disadvantageous to the taxpayer. For taxpayers with income of CZK 400,000, the total annual levies amount to CZK 59,772 , after conversion to months, the amount is CZK 4,981, which is CZK 488 less per month (CZK 5,856 per year) in comparison to flat rate. For taxpayers with income of CZK 600,000, the total annual levies amount to CZK 67,932, after conversion to months, the amount is CZK 5,661, which is CZK 192 more per month (CZK 2,304 per year) in this case a flat rate is advantageous to the taxpayer. For taxpayers with income of CZK 800,000, the total annual levies amount to CZK 79,932, after conversion to months, the amount is CZK 6,661, which is CZK 1,192 more per month (CZK 14,304 per year) in this case a flat rate is advantageous to the taxpayer. For taxpayers with income of CZK 1,000,000, the total annual levies amount to CZK 91,932, after conversion to months, the amount is CZK 7,661, which is CZK 2,192 more 
per month (CZK 26,304 per year) in this case a flat rate is advantageous to the taxpayer. The above mentioned can be illustrated in Figure 2.

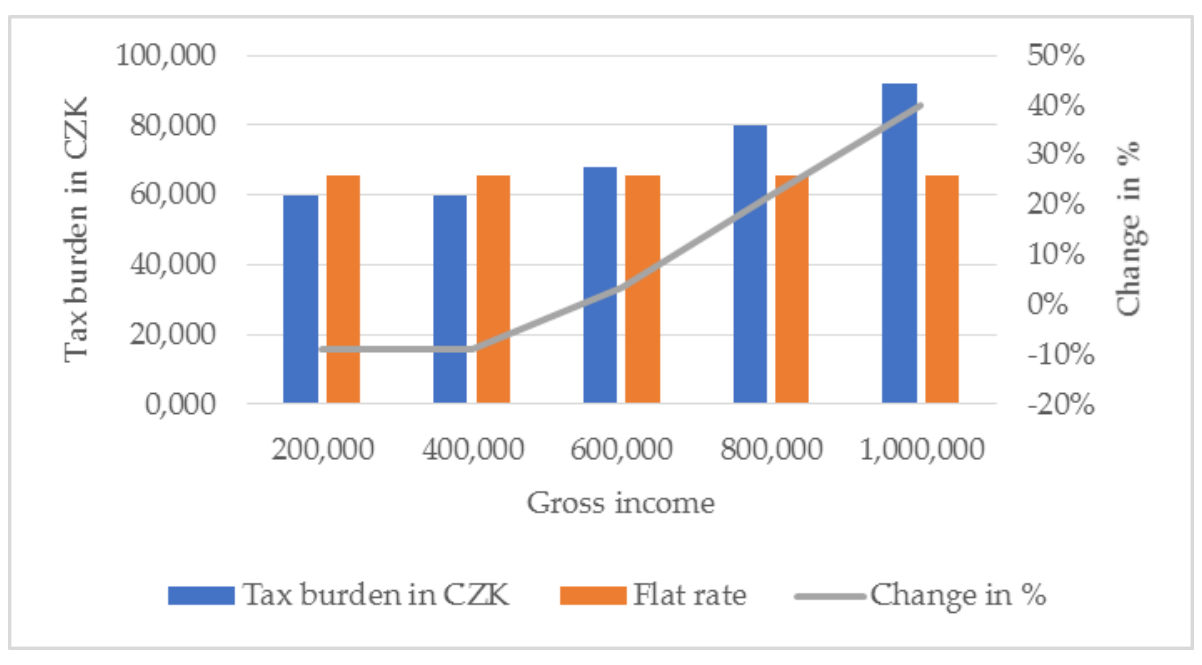

Figure 2. Introduction of a flat rate (60\% of income costs)

Table 5 shows the situation where the taxpayer applies life insurance in the amount of CZK 12,000 and paid interest on a construction loan in the amount of CZK 10,000, and a similar result can be seen as in the previous case.

Table 5. Introduction of a flat rate (60\% of income costs) - deducting non-taxable parts

\begin{tabular}{|c|c|c|c|c|c|}
\hline Text & $\mathbf{2 0 2 1}$ & $\mathbf{2 0 2 1}$ & $\mathbf{2 0 2 1}$ & $\mathbf{2 0 2 1}$ & $\mathbf{2 0 2 1}$ \\
\hline Income & 200,000 & 400,000 & 600,000 & 800,000 & $1,000,000$ \\
\hline Expenditure (60\%) & 120,000 & 240,000 & 360,000 & 480,000 & 600,000 \\
\hline $\begin{array}{c}\text { Tax base after } \\
\text { deducting non- } \\
\text { taxable parts }\end{array}$ & 58,000 & 138,000 & 218,000 & 298,000 & 378,000 \\
\hline Tax & 8,700 & 20700 & 32,700 & 44,700 & 56,700 \\
\hline Tax after discount & 0 & 0 & 4,905 & 16,860 & 28,860 \\
\hline Pension insurance & 31,056 & 31,056 & 31,056 & 31,056 & 31,056 \\
\hline Health insurance & 28,716 & 28,716 & 28,716 & 28,716 & 28,716 \\
\hline
\end{tabular}

Table 6 shows the situation where the taxpayer pays a tax benefit for the first child in the amount of CZK 15,204.

Table 6. Introduction of a flat rate ( $60 \%$ of income costs) - tax benefit for the first child

\begin{tabular}{|c|c|c|c|c|c|}
\hline Text & $\mathbf{2 0 2 1}$ & $\mathbf{2 0 2 1}$ & $\mathbf{2 0 2 1}$ & $\mathbf{2 0 2 1}$ & $\mathbf{2 0 2 1}$ \\
\hline Income & 200,000 & 400,000 & 600,000 & 800,000 & $1,000,000$ \\
\hline Expenditure (60\%) & 120,000 & 240,000 & 360,000 & 480,000 & 600,000 \\
\hline Tax base & 80,000 & 160,000 & 240,000 & 320,000 & 400,000 \\
\hline Tax & 12,000 & 24,000 & 36,000 & 48,000 & 60,000 \\
\hline Tax after discount & 0 & 0 & 8,160 & 20,160 & 32,160 \\
\hline Tax or tax bonus & $-15,204$ & $-15,204$ & $-7,044$ & 4,956 & 16,956 \\
\hline Pension insurance & 31,056 & 31,056 & 31,056 & 31,056 & 31,056 \\
\hline Health insurance & 28,716 & 28,716 & 28,716 & 28,716 & 28,716 \\
\hline
\end{tabular}

If the taxpayer claims a tax benefit for children, he needs to consider whether a lump sum is beneficial to him, as he will not be able to claim the tax bonus that can come to the 
amount mentioned in Table 4. Even if he opted for the lump sum, it is suitable for the other parent to claim a tax benefit for children.

Table 7 below shows the results of the hypothetical situations set out in Chapter 3 percentage of revenue of $40 \%$ ).

Table 7. Introduction of a flat rate (percentage of revenue of $40 \%$ )

\begin{tabular}{|c|c|c|c|c|c|}
\hline Text & $\mathbf{2 0 2 1}$ & $\mathbf{2 0 2 1}$ & $\mathbf{2 0 2 1}$ & $\mathbf{2 0 2 1}$ & $\mathbf{2 0 2 1}$ \\
\hline Income & 200,000 & 400,000 & 600,000 & 800,000 & $1,000,000$ \\
\hline Expenditure (40\%) & 80,000 & 160,000 & 240,000 & 320,000 & 400,000 \\
\hline Tax base & 120,000 & 240,000 & 360,000 & 480,000 & 600,000 \\
\hline Tax & 18,000 & 36000 & 54,000 & 72,000 & 90,000 \\
\hline Tax after discount & 0 & 8160 & 26,160 & 44,160 & 62,160 \\
\hline Pension insurance & 31,056 & 31,056 & 31,056 & 31,056 & 31,056 \\
\hline Health insurance & 28,716 & 28,716 & 28,716 & 28,716 & 28,716 \\
\hline
\end{tabular}

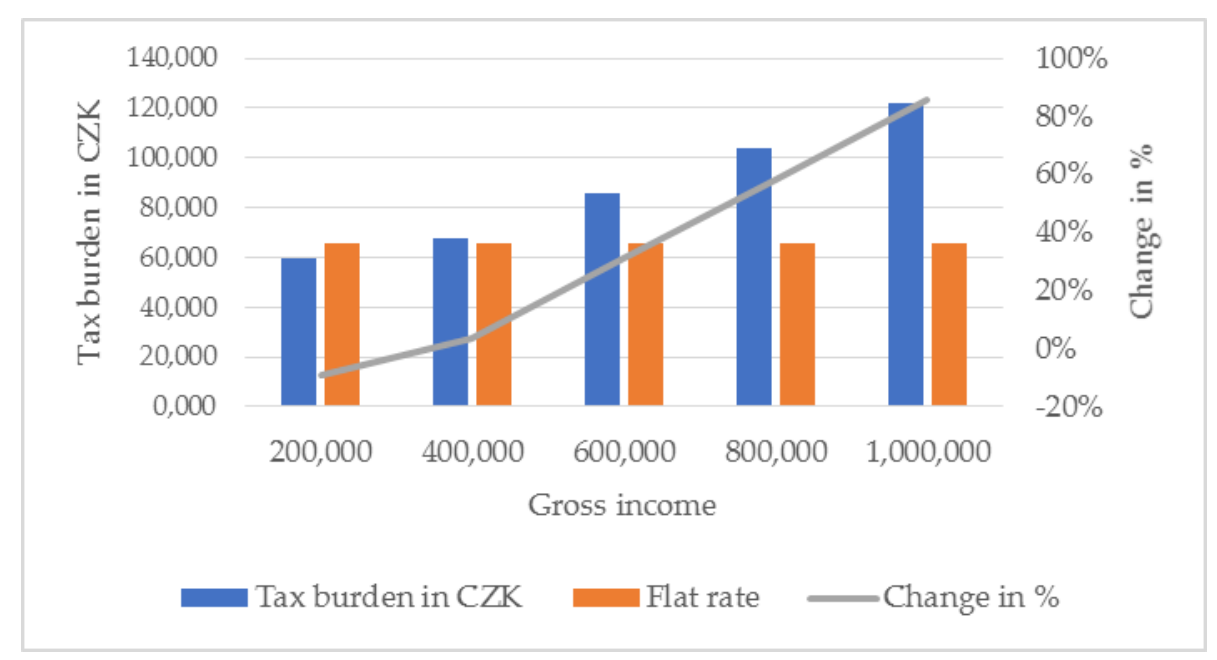

Figure 3. Introduction of a flat rate (60\% of income costs)

For taxpayers with income of CZK 200,000, the total annual levies amount to CZK 59,772, after conversion to months, the amount is CZK 4,981, which is CZK 488 less per month (CZK 5,856 per year) in comparison to flat rate and in this case a flat rate is disadvantageous to the taxpayer. For taxpayers with income of CZK 400,000, the total annual levies amount to CZK 67,932, after conversion to months, the amount is CZK 5,661, which is CZK 192 more per month (CZK 2,304 per year) in this case a flat rate is advantageous to the taxpayer. For taxpayers with income of CZK 600,000, the total annual levies amount to CZK 85,932, after conversion to months, the amount is CZK 7,161 which is CZK 1,692 more per month (CZK 20,304 per year) in this case a flat rate is advantageous to the taxpayer. For taxpayers with income of CZK 800,000, the total annual levies amount to CZK 103,932, after conversion to months, the amount is CZK 8,661, which is CZK 3,192 more per month (CZK 38,304 per year) in this case a flat rate is advantageous to the taxpayer. For taxpayers with income of CZK 1,000,000, the total annual levies amount to CZK 121,932, after conversion to months, the amount is CZK 10,161, which is CZK 4,692 more per month (CZK 56,304 per year) in this case a flat rate is advantageous to the taxpayer. The above mentioned can be illustrated in Figure 3. 


\section{Conclusions}

In the article, we tried to show, using model examples, how the adopted tax changes affect the taxpayer's net income. In case of the abolition of the super-gross wage, it was proved that it has a positive impact on the taxpayer's net income. His tax savings range in various cases from CZK 990 to CZK 2,050, depending on the amount of gross salary. In some cases, employees would not have to pay tax at all, if they applied the tax benefit to children, which was not analyzed in the article. When it comes to applying a catering flat rate, the most advantageous flat rate for employees is in the amount of CZK 75.6, it is exempt from taxes, and, in case of 21 working days a month it means an increase in net salary by CZK 1,587.6. If the employee requires a higher value of the catering flat rate, the above difference is part of the gross salary. Finally, we conclude that the introduction of a flat tax will not pay off for all self-employed people. The flat rate is beneficial only to self-employed persons who have an income of more than CZK 600,000, in the case of a $60 \%$ of income costs and more than CZK 400,000 in the case of a $40 \%$ of income costs. In the case of $80 \%$ of income costs, it will not pay off. However, this statement is rather illustrative, it always depends on the income of the selfemployed, the amount of insurance premiums, the amount of non-taxable parts of the tax base or the amount of the tax burden on children.

Acknowledgments: This research is supported by Project SP2021/51 at VSB-Technical University Ostrava.

\section{References}

Alfonso, A., \& Alegre, J. G. (2008). Economic Growth and Budgetary Components: A Panel Assessment for the EU. Empirical Economics, 41(3), 703-723. https://doi.org/10.1007/s00181-010-0400-9

Finanční správa. (2020, December 8). Paušální daň přehledně - jak a kdy platit měsiční zálohy. https://www.financnisprava.cz/cs/financni-sprava/media-a-verejnost/tiskove-zpravy/tz-2020/pausalnidan-prehledne-jak-a-kdy-platit-mesicni-zalohy-11052

Finance. (2016, August 19). Hledáme práci: Jaký plat zaměstnance odpovídá zisku OSVČ? https://www.finance.cz/zpravy/finance/355004-hledame-praci-jaky-plat-zamestnance-odpovida-ziskuosvel

Fuest, C., Peichl, A., \& Siegloch, S. (2018). Do Higher Corporate Taxes Reduce Wages? Micro Evidence from Germany. American Economic Review, 108(2), 393-418. https://doi.org/10.1257/aer.20130570

Hendl, J. (2005). Kvalitationí výzkum: Základní metody a aplikace. Praha: Portál, s.r.o.

KPMG. (2020a, September 8). Kdo vydělá na zrušení superhrubé mzdy? https://danovky.cz/cs/kdo-vydela-nazruseni-superhrube-mzdy

KPMG. (2020b, December 1). Daňový balíček 2021. https://danovky.cz/cs/danovy-balicek-2021

King, R. G., \& Rebelo, S. (1990). Public Policy and Economic Growth: Developing Neoclassical Implications. Journal of Political Economy, 98, 126-151. https://doi.org/10.3386/w3338

Krajňák, M. (2020a). Is Personal Income Tax on Dependent Activity in the Czech Republic Progressive? Politická ekonomie, 68(5), 534-553. https://doi.org/10.18267/j.polek.1295

Krajňák, M. (2020b). Analytic Hierarchy Process in Czech Taxpayers' Decision-Making Regarding their Tax Liability. Journal of Tax Reform, 2(6), 142-156. https://doi.org/10.15826/jtr.2020.6.2.079

Ministerstvo financí. (2020a, August 19). Rozhovor Aleny Schillerové o zrušení superhrubé mzdy. https://www.mfcr.cz/cs/aktualne/v-mediich/2020/rozhovor-aleny-schillerove-o-zruseni-sup-39219

Ministerstvo financí. (2020b, December 9). Na stravenkový paušál bude možné přispívat z FKSP. https://www.mfcr.cz/cs/aktualne/tiskove-zpravy/2020/na-stravenkovy-pausal-bude-mozne-prispiv40158

MPSV. (2020a, December 14). Minimální mzda. https://www.mpsv.cz/minimalni-mzda

MPSV. (2020b, December 18). Tisková zpráva. https://www.mpsv.cz/documents/20142/1248138/18_12_2020_TZ_Co_se_zmeni_od_1_1_2021.pdf/ 
Portal.Pohoda. (2020a, November 10). Připravovaná novinka na rok 2021: stravenkový paušál. https://portal.pohoda.cz/dane-ucetnictvi-mzdy/mzdy-a-prace/pripravovana-novinka-na-rok-2021stravenkovy-paus/

Portal.Pohoda. (2020b, October 19). Paušální daň od roku 2021. https://portal.pohoda.cz/pro-podnikatele/uzpodnikam/pausalni-dan-od-roku-2021/

Sokolovska, O. V. (2018). Current Trends in Labor Taxation in an Open Cconomy. Vestnik Sankt-Peterburgskogo Universiteta-Ekonomika-ST Petersburg University Journal of Economic Studies, 34(1), 77-94. https://doi.org/10.21638/11701/spbu05.2018.104

Slezák, J., Bieliková, A., \& Hakalová, J. (2020). Tax Burdens in the Czech Republic and Other European Union Countries in 2008-2018. In M. Staničková, L. Melecký, P. Doležalová, \& T. Powadová (Eds), Proceedings of the 5th International Conference on European Integration 2020 (pp. 791-798). Ostrava: VŠB-TU Ostrava, Faculty of Economics. https:/www.ekf.vsb.cz/export/sites/ekf/icei/.content/galerie-souboru/ICEI-2020Proceedings.pdf

Tikhonova, A., Goncharenko, L., Melnikova, N., \& Malkova, Y. (2018). An Assessment of the Influence of the Current National Economy Development State upon Personal Income Taxation System. In Soliman K. S. (Ed), Proceedings of the 32nd Conference of the International-Business-Information-Management-Association (IBIMA) (pp. 7982-7986). Sevilla, Spain. 